\title{
Validitas Pemeriksaan Antigen P24 HIV Metode Rapid Immunochromatography Terhadap Viral Load RNA HIV Metode PGR
}

\author{
Yanti, ${ }^{*}$ Ida Parwati, ${ }^{*}$ Agnes Rengga Indrati, ${ }^{\text {Anggraini Alam }}{ }^{* *}$ \\ ${ }^{*}$ Departemen Patologi Klinik, ${ }^{* *}$ Departemen Ilmu Kesehatan Anak Fakultas Kedokteran Universitas \\ Padjadjaran/RSUP Dr. Hasan Sadikin, Bandung
}

\begin{abstract}
Latar belakang. Bayi yang dilahirkan oleh ibu pengidap HIV/AIDS akan mengandung antibodi HIV ibu dalam darahnya, terdeteksi sampai usia 18 bulan. Pemeriksaan virologi (RNA/DNA HIV dan antigen p24 HIV) sesuai standar WHO adalah pemeriksaan HIV pada bayi dan anak < 18 bulan terlahir dari ibu HIV/ AIDS.

Tujuan. Mengetahui validitas pemeriksaan antigen p24 HIV metode rapid immunochromatogrpahy terhadap viral load RNA HIV metode PCR pada bayi dan anak $<18$ bulan dengan ibu HIV/AIDS.

Metode. Penelitian dilakukan di RSUP dr. Hasan Sadikin Bandung dan RSK Dharmais Jakarta, periode April-September 2013. Subjek penelitian adalah 72 bayi dan anak berusia $<18$ bulan yang lahir dari ibu HIV/AIDS.

Hasil. Sembilan (12,5\%) dari 72 subjek penelitian terdeteksi HIV pada pemeriksaan viral load RNA HIV, 2 $(22,2 \%)$ di antaranya positif pada pemeriksaan antigen p24 HIV. Didapatkan sensitivitas $22,2 \%$, spesifisitas $100 \%$, dan akurasi $90,3 \%$.

Kesimpulan. Pemeriksaan antigen p24 HIV metode rapid immunochromatography memiliki spesifisitas tinggi, sensitivitas rendah sehingga pemeriksaan antigen p24 HIV metode rapid immunohromatography ini dapat digunakan sebagai alat diagnostik. Sari Pediatri 2015;16(5):347-50.
\end{abstract}

Kata kunci: HIV, antigen p24 HIV, viral load RNA HIV, bayi <18 bulan

$\mathrm{I}$

nfeksi human immunodeficiency virus (HIV) merupakan masalah kesehatan dunia, terutama di negara sedang berkembang sejak 25 tahun yang lalu. ${ }^{1}$ Berdasarkan data epidemiologi tahun 2009,

\footnotetext{
Alamat korespondensi:

Dr. Anggraini Alam, Sp.A(K), Dr. Yanti. Departemen Ilmu Kesehatan Anak-Fakultas Kedokteran Universitas Padjadjaran. J1 Pasteur no 32 Bandung. Hp. 081348386558, 08122016430. E-mail: anggialam@yahoo. co.id, yantisiauta@gmail.com
}

World Health Organization (WHO) dan United Nation Acquired Immune Deficiency Syndrome (UNAIDS) melaporkan 2,5 juta bayi dan anak menderita HIV dan 370.000 di antaranya adalah kasus baru. Diperkirakan 260.000 bayi dan anak penderita HIV yang tidak mendapat terapi antiretrovirus (ARV) meninggal dunia. $^{2}$

Kementerian Kesehatan Republik Indonesia melaporkan 108.600 individu menderita HIV dan 43.667 individu menderita AIDS sampai dengan 
Juni $2013 .{ }^{3}$ Di dunia, setiap tahunnya diperkirakan 1,5 juta angka kematian bayi dan anak yang lahir dari ibu dengan HIV positif atau ibu dengan AIDS (ibu ODHA). Angka kematian meningkat $45 \%$ pada bayi berusia satu tahun dan 59\% pada anak berusia dua tahun tanpa terapi ARV. ${ }^{4}$

Antibodi HIV ibu dapat masuk melalui plasenta, terdeteksi sampai bayi dan anak berusia 18 bulan. Oleh karena itu, pemeriksaan HIV bayi dan anak berusia kurang dari 18 bulan yang lahir dari ibu ODHA, berbeda dengan pemeriksaan HIV pada anak lebih dari 18 bulan dan orang dewasa. ${ }^{5,6}$

Sesuai standar WHO, pemeriksaan RNA/DNA HIV metode PCR atau pemeriksaan viral load merupakan baku emas pemeriksaan HIV pada bayi dan anak kurang dari 18 bulan dengan sensitivitas $97 \%$ dan spesifitas $100 \%$, Namun, alat pemeriksaan ini tidak tersedia di semua fasilitas kesehatan karena membutuhkan biaya yang mahal dan tenaga yang terlatih, serta waktu yang lama dalam pengerjaannya. ${ }^{4}$

Antigen p24 HIV, secara biologi, sangat erat hubungannya dengan RNA HIV. Diperkirakan 2.0004.000 molekul p24 HIV dalam setiap virion HIV dan dapat terdeteksi dalam darah pada 11-13 hari setelah infeksi, mencapai puncak dalam satu bulan setelah infeksi HIV. Konsentrasi antigen p24 HIV menurun saat tubuh membentuk antibodi HIV, selanjutnya akan meninggi saat penderita HIV masuk ke dalam fase AIDS.?

Tujuan penelitian ini adalah mengetahui validitas pemeriksaan antigen p24 HIV metode rapid immunochromatography terhadap baku emas pemeriksaan viral load dengan metode PCR dalam menegakkan diagnosis HIV pada bayi dan anak berusia kurang dari 18 bulan yang lahir dari ibu ODHA.

\section{Metode}

Penelitian dilakukan sejak bulan April 2012 sampai dengan Oktober 2013 di Rumah Sakit Umum dr. Hasan Sadikin Bandung dan Rumah Sakit Kanker Dharmais Jakarta. Subjek penelitian adalah 72 bayi dan anak berusia kurang dari 18 bulan yang lahir dari ibu ODHA, diijinkan orang tuanya ikut dalam penelitian ini setelah menandatangani informed consent.

Darah subjek, $3 \mathrm{~mL}$, dimasukkan ke dalam tabung EDTA, kemudian disentrifus dengan kecepatan 3000 rpm selama 10 menit. Plasma dipisahkan ke dalam tabung mikro dan disimpan di dalam lemari pendingin pada suhu $-20^{\circ} \mathrm{C}$. Pemeriksaan viral load RNA HIV dan antigen p24 HIV metode rapid immunochromatography dilakukan setelah jumlah sampel minimal terpenuhi. Pemeriksaan antigen p24 HIV dilakukan dengan metode rapid immunochromatography,

Data karakteristik subjek penelitian yang dikumpulkan, berupa usia, cara partus, riwayat mendapat ASI dari ibu dengan terapi anti retrovirus (ARV), pemeriksaan viral load RNA HIV, dan antigen p24 HIV dilakukan setelah jumlah sampel minimal terkumpul.

Tabel 1. Hasil pemeriksaan viral load berdasarkan karakteristik subjek penelitian

\begin{tabular}{|c|c|c|c|}
\hline \multirow{2}{*}{ Variabel } & Viral load RNA (+) & Viral load RNA (-) & \multirow[b]{2}{*}{$\mathrm{p}$} \\
\hline & $\mathrm{n}=9(\%)$ & $\mathrm{n}=63(\%)$ & \\
\hline \multicolumn{4}{|c|}{ Usia kategori (bulan) } \\
\hline$<6$ & $0(0)$ & $25(39,6)$ & \multirow{3}{*}{$0,033^{\star}$} \\
\hline $6-8$ & $1(11,1)$ & $10(15,8)$ & \\
\hline $9-18$ & $8(88,8)$ & $28(44,4)$ & \\
\hline \multicolumn{4}{|l|}{ Cara partus } \\
\hline Spontan & $6(75)$ & $2(25)$ & \multirow[t]{2}{*}{$0,000^{*}$} \\
\hline Sectio caesaria & $3(4,7)$ & $61(95,3)$ & \\
\hline \multicolumn{4}{|c|}{ Riwayat mendapat ASI } \\
\hline $\mathrm{Ya}$ & $6(75)$ & $2(25)$ & \multirow[t]{2}{*}{$0,000^{*}$} \\
\hline Tidak & $3(4,7)$ & $61(95,3)$ & \\
\hline \multicolumn{4}{|l|}{ Ibu dengan ARV } \\
\hline $\mathrm{Ya}$ & $3(4,7)$ & $61(95,3)$ & \multirow[t]{2}{*}{$0,000^{*}$} \\
\hline Tidak & $6(75)$ & $2(25)$ & \\
\hline
\end{tabular}

Keterangan: Mann-whitney test: bermakna apabila $\mathrm{p}<0,05$ 
Tabel 2. Hasil uji diagnostik

\begin{tabular}{lcccc}
\hline & & \multicolumn{2}{c}{ Viral load RNA HIV metode PCR } & \multirow{2}{*}{ Total } \\
\cline { 2 - 4 } & & $(+)$ & $(-)$ & \\
\hline Antigen p24 & $(+)$ & 2 & 0 & 2 \\
HIV Metode & $(-)$ & 7 & 63 & 70 \\
Rapid ICT & & 9 & 63 & 72 \\
\hline Total & & & 63 \\
\hline
\end{tabular}

\section{Hasil}

Peneliti hanya menemukan $9(12,5 \%)$ dari 72 subjek penelitian yang memberikan hasil jumlah copy RNA HIV terdeteksi, yaitu pada kelompok usia 6-18 bulan. Berdasarkan perhitungan statistik, cara partus, riwayat mendapat air susu ibu dan riwayat ibu dengan ARV menunjukkan perbedaan yang bermakna dengan nilai $\mathrm{p}<0,001$ (Tabel 1 ). Uji validitas pemeriksaan antigen p24 HIV metode rapid immunochromatography terhadap baku emas viral load RNA HIV metode PCR mendapatkan hasil sensitivitas $22,2 \%$, spesifisitas $100 \%$, nilai prediksi positif $100 \%$, nilai prediksi negatif 90\%, dan akurasi 90,3\% ( Tabel 2).

\section{Pembahasan}

Badan kesehatan dunia WHO merekomendasikan pemeriksaan RNA/DNA HIV pada bayi yang lahir dari ibu ODHA dalam 48 jam setelah bayi lahir atau paling lambat dalam 4-6 minggu setelah bayi lahir. ${ }^{6}$ Peneliti menemukan semua subjek pada penelitian ini belum pernah melakukan pemeriksaan viral load RNA HIV. Informasi tersebut diperoleh peneliti melalui anamnesis pada saat orang tua subjek penelitian mengisi informed consent. Orang tua tidak memeriksakan viral load RNA HIV pada bayi dan anak mereka karena biayanya yang mahal. Pemeriksaan anti HIV akan dilakukan pada bayi dan anak mereka saat berusia 18 bulan sehingga biayanya lebih murah.

Hasil pemeriksaan viral load RNA HIV terdeteksi 9 dari 72 subjek penelitian. Enam dari sembilan subjek penelitian lahir spontan dan mendapat ASI dari ibu tanpa terapi ARV dan belum pernah mendapat terapi ARV sejak lahir. Sebelum pemeriksaan viral load RNA HIV dilakukan, 3 dari 6 subjek penelitian tersebut meninggal dunia. Ketiga subjek penelitian tersebut berusia antara 9-11 bulan dengan jumlah copy RNA HIV 650 copy RNA HIV, 500.000 copy RNA HIV, dan
1.500.000 copy RNA HIV. Lahir spontan, mendapat ASI, dan tidak mendapat terapi ARV merupakan faktor risiko penularan HIV dari ibu ODHA kepada bayi yang dilahirkan. ${ }^{8}$

Tiga dari sembilan subjek penelitian lainnya lahir secara sectio caesaria dari ibu yang mendapat terapi ARV dan tidak mendapat ASI. Ketiga ibu tersebut tidak mengetahui telah terinfeksi HIV sampai trimester dua usia kehamilan. Pemeriksaan anti HIV baru dilakukan pada trimester tiga usia kehamilan sehingga terapi ARV baru mereka dapatkan pada trimester tiga usia kehamilan. Pemberian terapi ARV yang terlambat akan meningkatkan risiko penularan HIV dari ibu ODHA kepada janin selama dalam kandungan. ${ }^{8}$

Hasil pemeriksaan viral load RNA HIV 63 dari 72 subjek tidak terdeteksi. Seluruh subjek penelitian tersebut lahir secara sectio caesaria dari ibu yang mendapat terapi ARV dan tidak mendapat ASI. Hasil viral load RNA HIV terdeteksi 6 dari 8 subjek penelitian yang partus secara spontan. Keadaan tersebut dapat terjadi karena kontak langsung antara mukosa mulut bayi dengan darah maternal, cairan amnion, cairan vagina atau cairan servikal yang mengandung HIV-1. Pada bayi dari ibu ODHA, penularan HIV dapat dicegah apabila ibu ODHA hamil partus secara sectio caesaria. ${ }^{8}$

Hasil pemeriksaan RNA HIV terdeteksi 6 dari 8 subjek penelitian yang mendapat ASI. Penelitian Read $^{9}$ menemukan bahwa kelainan mamae seperti abses, mastitis dan lesi daerah areola mamae pada ibu ODHA yang menyusui, kadar antivirus di dalam ASI yang rendah, serta mukosa mulut bayi yang mudah mengalami luka merupakan jalur penularan infeksi HIV-1 dari ibu ODHA kepada bayinya. ${ }^{9}$

Hasil viral load RNA HIV terdeteksi 6 (75\%) dari 8 subjek penelitian yang lahir dari ibu ODHA tanpa ARV. Penelitian ini menemukan terdapat perbedaan hasil viral load pada bayi antara ibu yang mendapat ARV dan tanpa ARV. Hal tersebut sesuai dengan penelitian Bateman ${ }^{8}$ yang menemukan 30\%-40\% ibu 
ODHA hamil tanpa ARV dapat menularkan HIV pada bayi selama hamil, saat partus, dan melalui ASI.

Hasil viral load RNA HIV terdeteksi 2 dari 9 subjek penelitian yang memberikan hasil positif pada pemeriksaan antigen p24 HIV metode rapid immunochromatography. Masing-masing subjek penelitian tersebut memiliki jumlah viral load 6.190.000 copy $\mathrm{RNA} / \mathrm{mL}$ dan $>10.000 .000$ copy $\mathrm{RNA} /$ $\mathrm{mL}$ darah. Kedua subjek penelitian tersebut berusia tujuh dan sepuluh bulan, lahir spontan pervaginam dari ibu yang tidak mendapat ARV selama hamil, dan keduanya mendapat ASI. Hal tersebut meningkatkan risiko penularan HIV dari ibu ODHA kepada bayi yang dilahirkan.

Fiscus dkk, ${ }^{10}$ Wittawatmongkol dkk, ${ }^{11}$, dan Parpia $\mathrm{dkk}^{4}$ mendapatkan sensitivitas antigen p24 HIV yang tinggi $(90 \%, 100 \%,>90 \%)$ pada sampel darah yang dilakukan pemanasan. Pemanasan menyebabkan lepasnya ikatan antara antigen dan antibodi HIV sehingga antigen p24 HIV berada dalam bentuk bebas dan mudah terikat dengan anti p24 HIV yang dilekatkan pada alat. ${ }^{4,10,11}$ Pada penelitian ini tidak dilakukan pemanasan karena sesuai dengan prosedur pengerjaan yang terdapat di dalam paket alat yang telah mendapat rekomendasi WHO pada tahun 2013 sebagai alat diagnosis infeksi HIV dengan konfirmasi alat lainnya, terutama di daerah yang tidak memiliki viral load RNA HIV metode PCR.

Sensitivitas penelitian ini adalah $22,2 \%$ dengan spesifisitas 100\%. Nilai spesifisitas lebih baik dibanding nilai sensitivitasnya sehingga penanda ini dapat digunakan sebagai alat diagnostik, tetapi belum dapat menyingkirkan adanya kemungkinan hasil negatif palsu. Hasil negatif palsu dapat disebabkan karena batas deteksi alat ini lebih tinggi daripada batas deteksi viral load RNA HIV dan waktu pemeriksaan antigen p24 HIV di dalam darah bayi dan anak yang kurang tepat.

Pemeriksaan antigen p24 HIV metode rapid immunochromatography memiliki spesifitas tinggi, tetapi sensitivitas rendah, dan akurasi tinggi dalam mendeteksi HIV pada bayi dan anak berusia kurang dari 18 bulan yang lahir dari ibu ODHA, terhadap viral load RNA HIV. Alat pemeriksaan ini dapat digunakan untuk menegakkan diagnosis dini HIV pada bayi dan anak berusia kurang dari 18 bulan yang lahir dari ibu ODHA, terutama di daerah yang tidak memiliki alat dengan metode PCR. Hasil positif memastikan adanya infeksi HIV, tetapi hasil yang negatif perlu dikonfirmasi dengan pemeriksaan viral load RNA HIV.

\section{Daftar pustaka}

1. AIDS epidemic update 2001. Trop Doct 2002 ;32: 189.

2. Zvandyadza GF. Pediatric HIV testing challenges in resource limited settings. Dalam: Diaz PR, penyunting. HIV Testing. Europe: Intech;2012. h. 103-9.

3. KEMKES RI. Perkembangan HIV \& AIDS di Indonesia Triwulan II Tahun 2013. Pusat Komunikasi Publik Kementrian Kesehatan Republik Indonesia. 2013. Diakses 10 November 2013. Didapat dari: kontak@ depkes.go.id.

4. Parpia ZA, Elghanian R, Nabatiyan A, Hardie DR, Kelso DM. p24 Antigen rapid test for diagnosis of acute pediatric HIV infection. JAIDS 2010;55:413-9

5. Violari A, Colton M, Gibb D, Bebeker A, Steyn J, Phillip J. Antiretroviral therapy initiated before 12 weeks of age reduce early mortality in young HIV infected infant: evidence from the children with HIV early antiretroviral therapy (CHER) Study. $4^{\text {th }}$ International AIDS Conference on HIV Pathogenesis Treatment and Prevention; July 22-25. Sydney Australia: NSPiSA; 2007.

6. WHO. Recomendations on the diagnosis of HIV infection in infants and children. HIV/AIDS Programme, WHO;2009.h. 3-45.

7. Baveja UK, Verghese A, Chattopadhya D, Shivial. Evaluation of levels of p24 antigen in HIV/AIDS cases and corellation with CD4 T cell counts. JIACM 2008;9:103-7.

8. Bateman C. Mother and babies - widening the HIV safety net. South African Med J 2011;101:8.

9. Read JS. Human milk, breastfeeding, and transmission of human immunodeficiency virus type 1 in the United States. Pediatrics. 2003;112:1196-205.

10. Fiscus SA, Wiener J, Abrams EJ, Bulterys M, Cachafeiro A, Respess RA. Ultrasensitive p24 antigen assay for diagnosis of perinatal human immunodeficiency virus type 1 infection. J Clin Microbiol 2007;45:2247-77.

11. Wittawatmongkol O, Vanprapar N, Cherskul P, Phongsamart W, Prasit. Boasted p24 antigen assay for early diagnosis of perinatal HIV infection. J Med Assoc Thai 2010;93:187-90. 